DOI:10.17951/k.2020.27.2.171-174

\begin{tabular}{lcc}
\hline & A N N A L E S \\
UNIVERSITATIS MARIAE CURIE-SKŁODOWSKA & LUBLIN - POLONIA \\
VOL. XXVII, 2 & SECTIOK \\
\hline
\end{tabular}

Reviews. Reports

Recenzje. Sprawozdania

ANNA SŁUPEK

\title{
Review of: Chantal Mouffe, For a Left Populism, Verso, London 2018, pp. 93
}

The introduction to the latest book of Chantal Mouffe communicates to the reader the most important attempt of her paper. The aim is a great need for the left to understand a challenge arising out of a current situation in politics, called by Mouffe "populist moment". The stake in the line of this work is very high as Mouffe claims. The left could take advantage of this opportunity and impose a new vision of the political - to favor stronger democratic politics [Mouffe 2018: 1].

It is worth pointing out that Mouffe in her study does not seek to deepen studies of the nature of populism. The ambition of the author is rather political - Mouffe openly calls the book a "political intervention" [Mouffe 2018: 8]. She tends to name the political time we are in. This is, in a sense, a crisis moment for the left, which shows an analogy to the circumstances of writing Mouffe's previous publications.

The book Hegemony and Socialist Strategy from 1985, written together with Ernesto Laclau during the crisis of leftist thought, concerned the period after the 1968 revolution when political relations could no longer be classified in terms of classes. On the Political, on the other hand, was about the left-wing crisis caused by the hegemony of neoliberalism. The crisis which left-wing parties face today is caused by the domination of right-wing populists. Mouffe calls this political time a "populist moment" [Mouffe 2018: 5-7].

Mouffe uses an argumentative strategy taken from Machiavelli, consisting of presenting phenomena in the category of conjuncture. For Mouffe, the "populist moment" is therefore a kind of conjuncture in Western Europe, which is destabilizing 
the current political situation. As a result of unmet demands, the people oppose the political elite, seeking an opportunity to repair an unjust political system [Mouffe 2018: 10-11].

The "populist moment" is then a collection of various forms of rebellion against neoliberal hegemony. This hegemony contributed to the erosion of the democratic system known as post-democracy. In The Democratic Paradox, Mouffe devoted a lot of attention to the dual nature of liberal democracy. The combination of two elements in itself - the democratic principle of people's sovereignty with the liberal principle of individual freedom - determines the irremovable tension accompanying democracy. The post-democratic system, however, adopted a strategy of favouring the liberal dimension exclusively [Mouffe 2005: 62-64].

Mouffe believes that the post-democratic context is significant for understanding the "populist moment". In her opinion, the erosion of democratic values and the undermining of the principle of equality and sovereignty of the people are extremely important for the universality of the resistance felt by the people currently. This resistance is directed against the elite who have failed to listen to society [Mouffe 2018: 16-18].

In the emotion of social discontent during the "populist moment", Mouffe sees the potential to shift the paradigm of political thinking into a more inclusive and pluralistic one. In the affective dimension of the current political situation, Mouffe sees the potential to establish a new hegemony. At this point, the distinction between right-wing and left-wing populism should be highlighted in Mouffe's approach [Mouffe 2018: 22-23].

Mouffe does not consider the phenomenon of populism in general as a threat to the survival of the democratic order. In a way, she considers it as a natural consequence of the many years of oppressive neoliberalism. However, Mouffe believes that the political conjuncture on populism is not essentially right-wing. If we agree, in line with Mouffe's assumption, that the essence of the populist moment is the affective dimension of the conflict between the people and the elites, it is possible to regain voters through the left-wing populist strategy as well.

The difference between right-wing and left-wing populism, Mouffe argues, lies in the construction of "us" and "them". Right-wing populism defines demos based on the concept of a nation. It is a concept that excludes many from the community, treating, for example, immigrants as a threat to the nation. On the other hand, the category of adversary of a people is constructed against post-democracy, but not necessarily against neoliberal forces. Thus, the threat related to right-wing populism is associated not only with nationalism, but also with the consolidation of neoliberal hegemony - and, consequently, the weakening of democracy [Mouffe 2018: 23].

According to Mouffe, the left-wing construction of the people should be based on an anti-essentialist approach, which she already postulated in Hegemony and Socialist Strategy. The populist left should represent the interests of the working people, including immigrants, the precariat, and the LGBT+ community. Such an 
inclusive concept of the people has a chance to revive and radicalize the democratic system [Mouffe 2018: 23-24].

Mouffe devotes much attention to the concept of radicalization of democracy. This concept is based on the possibility of creating a fairer democratic system within the existing institutions. The author emphasizes that her position is in no sense revolutionary - she advocates a profound implementation of constitutive democratic principles. Mouffe believes that the strategy of left populism she proposes is capable of achieving this goal [Mouffe 2018: 42-43].

In practical terms, left populism would establish a new hegemonic order within the liberal-democratic system. The new hegemonic order would consist in the construction of the universal will that would allow the re-articulation of the order of liberal democracy, but with a privilege for the democratic element [Mouffe 2018: 44].

Interestingly, Mouffe addresses the challenge of the "populist moment" to new left-wing movements, sometimes considered extreme left and often marginalized. She sees no chance for a credible presentation of populist postulates by social democratic parties which used to implement Giddens' theory of the Third Way.

Mouffe explains this in a section on the critique of neoliberalism, suggesting that it is impossible to establish a new hegemonic order without drawing a dividing line between the center-right and the center-left. From the perspective of conflictual theory of the political that Mouffe advocates, it is impossible to act without identifying the opponent, which is something the social democrats, who favour consensual democracy, refuse to do.

Mouffe therefore considers the new European parties as the populist left, such as the Spanish Podemos and Greek Syriza, or the reformed British Labor Party led by Corbyn. At the same time, Mouffe points out that the growing popularity of these parties at the time proves the importance of the populist moment and the chances of building a left-wing hegemony.

It should be emphasised that Mouffe, apart from pointing out that the priority should be to fight the injustice of the neoliberal system, does not explicitly define what the strategy of the populist left should be. She indicates almost exclusively ideological priorities, rather than a political strategy per se. However, according to Mouffe, the populist strategy is primarily a way of constructing the category of the people. Thus, she privileges the axiological dimension of political activity and considers the defense of equality and social justice as the most important features of the left.

It is also worth pointing out that Mouffe is an advocate of using the categories of the left and the right. Although many theorists consider them outdated, Mouffe says they are still an important point of reference in public discourse. In this way, she underlines the importance of the distinction she made between right-wing and left-wing populism.

Mouffe presents a remarkable theory. The thread of the non-negative perception of populism is particularly interesting. In the maze of common accusations of pop- 
ulism against anyone we disagree with, such an observation seems to be refreshing to the discussion. However, that was not Mouffe's goal to deepen the study on the nature of populism. From the beginning of her scientific activity, Mouffe has been striving to define the position of the left on the political scene. In her opinion, the populist moment is a chance for new movements of the left to break out of the stagnation of unpopularity.

Mouffe's theory, however, seems to be inconsistent with reality, as the parties that Mouffe saw as potentially aiming at creating a left-wing hegemony, such as Syriza, Podemos, and the British Labor Party, lost their relevance on the political scene and have no chance to impose a new hegemony. The situation is similar in the United States, where a politician from the middle of the neo-liberal elite of the Democratic Party not only defeated left-wing populist Bernie Sanders in the primary elections but also won - despite the populist moment - in the general presidential election.

The theory of left-wing populism fits perfectly to the whole of Mouffe's political theory. The problem, however, is that, as she emphasizes, the activist dimension of her ideas is the most significant. Therefore, it should be assessed through the prism of political utility, not only philosophical importance. However, looking from this perspective, it is impossible to defend some of the theses contained in the book.

\section{BIBLIOGRAPHY}

Mouffe, Ch. 2005. Paradoks demokracji, Wydawnictwo Naukowe Dolnośląskiej Szkoły Wyższej Edukacji TWP, Wrocław.

Mouffe, Ch. 2018. For a Left Populism, Verso, London. 